\title{
Unusual Submucosal Haemotoma in Esophagus on Upper G.I. Endoscopy
}

\author{
Zubin Pradeep Sharma*, Ravindra Sharma and Divya Sharma \\ Aditya Hospital and Gastroenterology Centre, Rajasthan, India
}

Submission: May 08, 2020; Published: June 12, 2020

*Corresponding author: Zubin Pradeep Sharma, Aditya Hospital and Gastroenterology Centre, Rajasthan, India

Keywords: Esophageal submucosal haemotoma; Upper gastrointestinal tract; Hematemesis; Esophageal hematoma

\section{Short Communication}

Esophageal submucosal haemotoma is one of the rare disorders of upper gastro intestinal tract and it is considered to be a form of injury to esophagus. There are two types of esophageal injuries: mechanical and chemical injuries. Mechanical injury is subdivided into traumatic and spontaneous ones. Here we present a case of submucosal haemotoma associated with opium intake.

A 39-year-old male came to our hospital with history of hematemesis ( 2 epsiodes) after taking opium in large quantity for the past 2 days. He was not a opium addict with no other addict documented. No co-morbidity or underlying diseases were found in this patient. Laboratory investigations showed elevated
C-reactive protein level $(12.45 \mathrm{mg} / \mathrm{dl})$, ESR $76 \mathrm{~mm}$. Rest of the blood investigations - liver, kidney function, coagulation profile was normal. Upper G.I. Endoscopy showed an extensive longitudinal submucosal esophageal hematoma, extending from $23 \mathrm{~cm}$ from the incisors till $42 \mathrm{~cm}$ involving gastroesophageal junction (G.E.). The esophageal lumen showed hyperemia with moderate congestion. No active bleeding noticed on touching, and no foreign body was noticed. Patient was kept nil by mouth and was given conservative treatment and after 5 days repeat endoscopy was done which showed that the hematoma had completely resolved and a shallow ulcer was noticed at the original lesion (Figure 1).

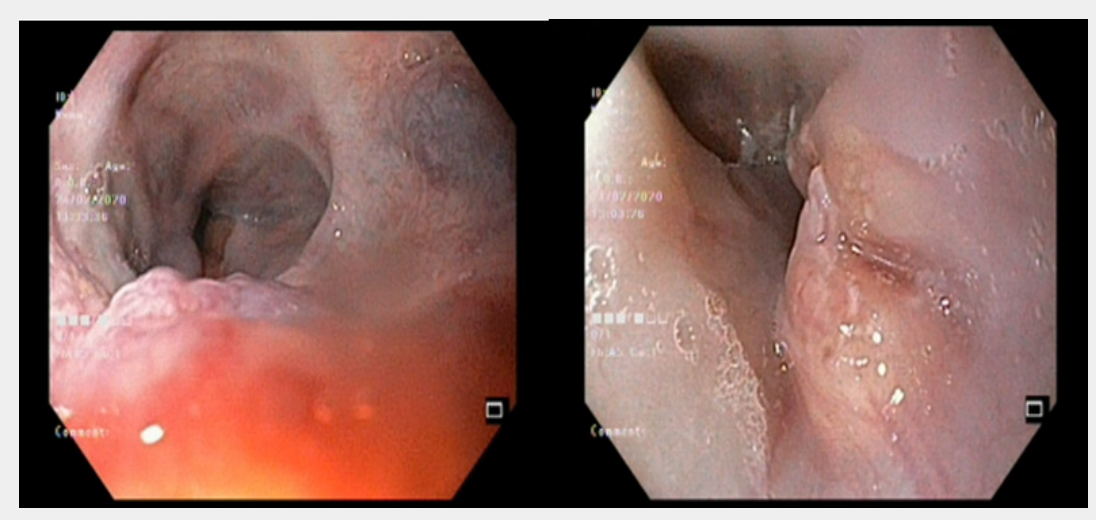

Figure 1: Unusual submucosal haemotoma in esophagus on upper G.I. endoscopy.

Esophageal hematoma is a very rare phenomenon in clinical day to day endoscopic practice. Previous reports regarding the causes of esophageal hematoma have referred mainly to complications of endoscopy [1]; other reported cases were caused by hard food boluses impaction, coagulopathy, trauma, drugs or idiopathic [2,3]. Symptoms of esophageal hematoma are hematemesis, epigastric 
pain, heartburn, and odynophagia. Differential diagnosis includes aorto-esophageal fistula, esophageal neoplasm, esophageal perforation and aortic dissection. The treatment of esophageal hematomas depends on the clinical situation. In many studies, the patients respond well to conservative treatment. However, surgical intervention is required when severe bleeding occurs. We present these findings to raise awareness of the imaging features of this phenomenon.

\section{References}

1. Lin AW, Eng M, Robbins D (2009) A very unusual appearance of a rare endoscopic finding: esophageal hematoma. Endoscopy 41(Suppl 2): E40.

2. Lawrence J, Brandt T (2008) Rare cause of melena: spontaneous esophageal hematoma. Gastrointest Endosc 67(3): 123-125.

3. SA Seneviratne, DS Kumara, A Drahaman (2012) Spontaneous intramural oesophageal haematoma: a case report," Medical Journal of Malaysia 67(5): 536-537.

This work is licensed under Creative Commons Attribution 4.0 License

DOI:10.19080/ARGH.2020.15.555911

\section{Your next submission with JuniperPublishers will reach you the below assets}

- Quality Editorial service

- Swift Peer Review

- Reprints availability

- E-prints Service

- Manuscript Podcast for convenient understanding

- Global attainment for your research

- Manuscript accessibility in different formats ( Pdf, E-pub, Full Text, audio)

- Unceasing customer service

Track the below URL for one-step submission https://juniperpublishers.com/online-submission.php 